\title{
VIRAL DISEASES OF WHEAT AND THEIR MAIN CARRIER IN THE CONDITIONS OF LOWER VOLGA
}

\author{
T.S. Markelova, E.A. Baukenova \\ Research and Development Institute of Agriculture of the South-East, RAAS, 7, ul. Tulaikova, Saratov, 410010 Russia \\ e-mail: tsmarkelova@bk.ru,raiser_saratov@mail.ru
}

Received August 28, 2012

$\mathrm{S}$ u m m a r y

Of numerous diseases of agricultural plants, the viral and mycoplasmal diseases cause the biggest losses. The most widespread wheat viral diseases in lower Volga are the Russian winter wheat mosaic, mosaic of awnless brome, barley yellow dwarf and wheat pale green dwarf, the last one caused by a mycoplasma infection. The large majority of phytopathogenic viruses are distributed by insect vectors, which, as a rule, are virus-specific and often provide not only the transfer of virus particles but also their long-time keeping, multiplication and virulence rising. The presented investigations in $2010-2011$ suggested that high amount of leafhoppers, their virus-carrying, and also favorable weather conditions are basic factors for the spreading of viral infection on wheat plants. The dynamics of leafhoppers number was investigated on two winter wheat varieties and two spring ones, the degree of development of complex viral diseases on culture was studied. It was shown that in 2011 significant reduction of carrier population (as compared with 2010$)$ resulted in decrease of prevalence of viral infection both on spring and winter wheat. Both on spring and winter wheat the first symptoms of infection can be already observed at tillering. At the earing phase the majority of infected plants does not form the ear or are lost entirely.

Keywords: wheat, virus diseases, insect vector.

Grain production is the main agricultural industry in arid conditions of the Volga region. However, yields of wheat closely depend on the extension of its most significant pathogens - viral diseases and mycoplasmas (1). There are 19 viral infections of wheat known in the territory of the former Soviet Union (2). The constant threat of viral epiphytoties is provided by the natural foci where infection persists and circulates between wild cereals - carriers - wild cereals. Viruses can move from one group of cereals to others via seasonal migrations of insect carriers in crop rotations oversaturated with cereal crops (3). Viral infection of plants leads to disturbances of carbohydrate and nitrogen metabolisms, reduce in activity of key enzymes and suppression of the associated growth processes, and significant loss of yields (4). Unlike viruses and fungi, bacteria penetrate in plants only through a damaged surface (5) of a small size, because in cases of extensive necrosis and fast cell death the pathogen is blocked and the infection can't be transmitted. Once infected by a virus, a plant becomes its constant carrier with almost no exceptions (3).

The control of viral diseases of cereals is based on the knowledge of their peculiarities and viral circulation in nature, as well as biology of vectors (6). Insect vectors (7) are usually virus-specific; along with mechanical transfer of viral particles they often provide their long-term preservation, propagation and growth of virulence. The effect of a virus transfer depends on viruliferous properties of the insect population (number of virus carriers), developmental stage of plants, and weather conditions. Leafhoppers have piercing-sucking mouthparts, so they often serve as vectors for many phytopathogenic viruses and mycoplasmas. These insects are quite mobile: nymphs and adults quickly jump from plant to plant on the modified hind legs, adults can fly at long distances. Viruses transmitted by leafhoppers have a propagative type of transfer - they proliferate in the carrier until the certain accumulated level when the insect is capable to infect plants (3). Viruliferous leafhoppers may show some pathological changes during proliferation of viruses, i.e. the viruses biologically associated with leafhoppers are pathogens not only for plants, but for their hosts too (3).

In the Volga region, the most common viral diseases of wheat are winter wheat Russian mosaic virus (WWRMV), Brome mosaic virus (BMV), barley yellow dwarf (BYD) virus, and wheat pale green dwarf (WPGD) disease caused by mycoplasma (8). The most harmful is the first one, WWRMV (4). The virus affects both winter and spring wheats, rye, barley, millet, oats, and wild cereals - foxtail (Setaria glauca Beauv., S. viridis Beauv.) and reed grass (Calamagrostis epigeios) (9). WWRMV is transmitted by leafhoppers (Psammotettix striatus L., Macrosfeles laevis L.). Eggs of both species overwinter in winter wheat crops, larvae hatch in May and feed on stems and leaves in ground parts of plants. The virus transfer from females to progeny or by feeding on infected plants that maintain the infection overwinter. The rate of transovarial transmission of WWRMV in the leafhopper $P$. striatus is about $76 \%$, for which it is known as one of major reservations of this infection (3).

The number of viruliferous individuals in summer amounts $2 \%$ or more, though the summer infestation of plants is usually low harmful due to a long latent period and relatively low susceptibility of mature plants. In the stage of milk and wax ripening of wheat, leafhopper adults migrate to spring wheat, rye, maize, millet, and other cereals where they feed and produce the $2^{\text {nd }}$ generation in July and August. In autumn (end of September), leafhoppers come into sprouts of winter cereal crops, where they feed and lay overwintering eggs (10). In the autumn population of leafhoppers the number of viruliferous individuals is less than $1 \%$. Therefore, in years with early start of a cold season, winter crops are weakly affected by WWRMV (usually 1-6 \%). Long warm autumn increases probability of the infection to 20-30\%, as the vectors often change locations of feeding. In such cases, yield loss may amount $15-20$ $\%$ (11). Early symptoms of the disease appear already in autumn: mosaic color and yellowing of leaves that sometimes curl up in a tube. The most severe symptoms are observed in late May and early June, at booting and early earing: abnormal variation of tillering, growth stunt, and death of some plants.

The authors have studied the population dynamics of leafhopper Psammotettix striatus L. and its effect on the extension and development of winter wheat Russian mosaic virus (WWRMV) in the Low Volga region.

Tecnique. The observations were carried out in 2010-2011 at the experimental fields of Research and Development Institute of Agriculture of the South-East (NIISKh of the South-East). Climate of the region - dry continental, the sum of active temperatures 2500-2700 ${ }^{\circ} \mathrm{C}$, average annual precipitation - $392 \mathrm{~mm}$. Investigations were conducted on spring wheat (cv Saratovskaya 68 , cv Saratovskaya 73) and winter wheat (cv Saratovskaya 17, cv Saratovskaya 90). Seeds (400 pcs $/ \mathrm{m}^{2}$ ) were sown with plot seeder SSFK7 (Russia) on clean fallow after cultivation, the acreage -5 hectares for each cultivar; no chemical treatments were performed during 
the growing season of plants.

Population dynamics of adult leafhoppers was studied according to the classical scheme with sampling by a standard sweepnet: 25 sweeps at 4 replicates in every 10 steps along the diagonal of a field. Once a week the extra sampling was performed at edges of the fields along forest belts where the crops usually grow sparser and accumulate the insect vectors.

The extent of damage from viral diseases on plants was determined using the method of G.M. Razvyazkina (12). The first account was conducted during the phenophase at which symptoms of the infection were the most pronounced: in winter varieties - in autumn during tillering, in spring - in1.0-1.5 months after the emergence of sprouts. Route surveys of the fields were performed on the record plots of $1 \mathrm{~m}^{2}$ located diagonally across the field at a distance of $20 \mathrm{~m}$ from each other (total 10 plots in each cultivar), where all plants were inspected to determine the proportion (\%) of plants with severe symptoms of the disease (12). The degree of damage was assessed by points: 0 - no damaged plants, 1 - single damaged plants (1-5\% of total), 2 - low damage (5-10 \% damaged plants), 3 - medium damage (10-30\% damaged plants), 4 - high damage (more than $30 \%$ damaged plants).

Results. In weather records of the Laboratory of Agricultural Meteorology of NIISKh of the South-East, growing season of the year 2010 was a sever draught: monthly precipitation in May was $33.8 \mathrm{~mm}$, in June - $18.8 \mathrm{~mm}$, in July - $19.9 \mathrm{~mm}$, and no precipitation in August. The maximum temperature in July and August raised up to $40{ }^{\circ} \mathrm{C}$. The year 2011 was more favorable for vegetation of wheat than 2011. The maximum temperature in summer of 2011 did not exceed $38{ }^{\circ} \mathrm{C}$, total precipitation in April - 17.0 $\mathrm{mm}$, in May $-12.3 \mathrm{~mm}$, in June $-62.7 \mathrm{~mm}$, in July - $4.9 \mathrm{~mm}$, in August $-19.9 \mathrm{~mm}$.

In the authors' observations, the leafhopper (P. striatus L.) was recorded as the only vector of WWRMV.

1. Population of leafhopper Psammotettix striatus L. accounted on two varieties of winter wheat in different years of observation (experimental field of Research and Development Institute of Agriculture of the South-East, Saratov)

\begin{tabular}{|c|c|c|c|c|c|}
\hline \multirow{3}{*}{$\begin{array}{l}\text { Month, } \\
\text { ten-day pe- } \\
\text { riod }\end{array}$} & \multirow{3}{*}{$\begin{array}{l}\text { Phase of devel- } \\
\text { opment }\end{array}$} & \multicolumn{4}{|c|}{ Population - number of individuals } \\
\hline & & \multicolumn{2}{|c|}{2010} & \multicolumn{2}{|c|}{2011} \\
\hline & & Saratovskaya 17 & Saratovskaya 90 & Saratovskaya 17 & Saratovskaya 90 \\
\hline September, III & Sprouts & 54 & 63 & 17 & 12 \\
\hline October, I & Tillering & 45 & 51 & 15 & 13 \\
\hline May, I & Tillering & 39 & 47 & 0 & 0 \\
\hline May, II-III & Booting & 200 & 193 & 51 & 53 \\
\hline June, II & Earing & 118 & 110 & 42 & 47 \\
\hline June, III & Flowering & 70 & 81 & 31 & 25 \\
\hline July, I & Grain formation & 70 & 69 & 30 & 32 \\
\hline \multirow[t]{2}{*}{ July, II } & Milk ripeness & 61 & 59 & 25 & 25 \\
\hline & Milky-wax ripeness & 42 & 50 & 23 & 27 \\
\hline \multirow[t]{2}{*}{ July, III } & Wax ripeness & 19 & 23 & 15 & 20 \\
\hline & Complete ripeness & 14 & 16 & 0 & 10 \\
\hline
\end{tabular}

The year 2010 was favorable for development of leafhoppers (Table 1). Their population peak on winter wheat was recorded at booting (200 insects per 25 sweeps of a sweep-net), then it decreased with maturation of the plants. In the phase of complete ripeness, the number of leafhoppers did not exceed 14-16 individuals. In autumn 2010, the insects were observed in winter wheat already at sprouting and then were infrequent at tillering as they passed to wintering.

In 2011, population of leafhoppers was comparatively smaller than in 2010. The development of individuals was more uniform and, therefore, population size had no sharp fluctuations during the growing season. Along with it, in 2011, leafhoppers abandoned winter wheat at milky-wax ripeness for more luscious spring crops where they accumulated in the edge belts adjacent to the winter wheat crops.

In 2010, adult leafhoppers were observed in sprouts of spring wheat (on average 59 insects per 25 sweeps) (Table 2). The number of the insects increased with development of plants, and the largest population was recorded on spring wheat at booting. The reduce in number of leafhoppers coincided with maturation of wheat plants, most likely due to migration of the insects on other feed sources, such as wild cereals .

In 2011, the number of leafhoppers on spring wheat was significantly lower than in 2010. The first individuals were recorded only at booting. In I and II ten-day period of May no insects were observed, probably because of unfavorable climatic conditions of wintering in 2010. The maximum number of leafhoppers was observed during earing; adult insects accumulated along forest belts, and the number of insects decreased diagonally forwards the edges.

2. Population of leafhopper Psammotettix striatus L. accounted on two varieties of spring wheat in different years of observation (experimental field of Research and Development Institute of Agriculture of the South-East, Saratov)

\begin{tabular}{|c|c|c|c|c|c|}
\hline \multirow{3}{*}{$\begin{array}{l}\text { Month, } \\
\text { ten-day } \\
\text { period }\end{array}$} & \multirow{3}{*}{ Phase of development } & \multicolumn{4}{|c|}{ Population - number of individuals } \\
\hline & & \multicolumn{2}{|c|}{2010} & \multicolumn{2}{|c|}{2011} \\
\hline & & Saratovskaya 68 & Saratovskaya 73 & Saratovskaya 68 & Saratovskaya 73 \\
\hline May, I & Sprouts & 59 & 33 & 0 & 0 \\
\hline May, II & Tillering & 110 & 126 & 0 & 0 \\
\hline May, III & Onset of booting & 117 & 130 & 9 & 13 \\
\hline June, I & Booting & 182 & 173 & 27 & 33 \\
\hline June, II & Earing & 109 & 88 & 70 & 69 \\
\hline June, III & Flowering & 57 & 61 & 46 & 54 \\
\hline June, I & Grain formation & 53 & 55 & 38 & 42 \\
\hline \multirow[t]{2}{*}{ July, II } & Milk ripeness & 48 & 57 & 23 & 27 \\
\hline & Milky-wax ripeness & 33 & 28 & 26 & 18 \\
\hline \multirow[t]{2}{*}{ July, III } & Wax ripeness & 18 & 15 & 16 & 14 \\
\hline & Complete ripeness & 12 & 15 & 11 & 10 \\
\hline
\end{tabular}

The observed differences in development of leafhoppers were expressed by the chart of population dynamics of $P$. striatus L. on spring wheat variety Saratovskaya 68 during the observation period of vegetation (Fig. 1) (population decline, population peak 
shifted to the later phenophase, and relatively uniform propagation of insects in the year favorable for plant growth).

Comparing the population dynamics of leafhoppers as main viruliferous insects on wheat with the data on development of viral diseases in this crop, it can be concluded that the significant reduce in population of the year 2011 (compared with 2010) contributed to the decrease in WWRMV damage of both spring and winter wheats (Table 3, Fig. 2).

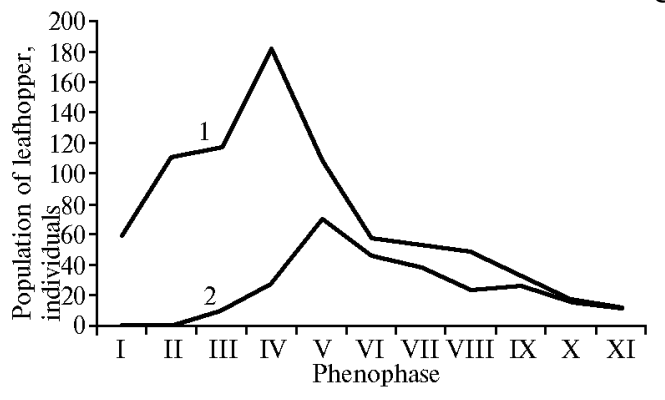

Fig. 1. Population dynamics of leafhopper Psammotettix striatus $\mathrm{L}$. during the vegetation of spring wheat $\mathrm{cv}$ Saratovskaya 68 by phenophases in different years of observation: $1-2010,2-2011$; I - sprouts, II tillering, III - onset of booting, IV — booting, V - earing, VI - flowering, VII - grain formation, VIII - milk ripeness, IX - milky-wax ripeness, $\mathrm{X}$ - wax ripeness, $\mathrm{XI}$ - complete ripeness. Number of individuals was counted per 25 sweeps of a sweep-net (mean of 4 repetitions; experimental field of Research and Development Institute of Agriculture of the South-East, Saratov)
It is known that viral diseases of cereal crops normally may be not recorded for a long time, or weakly manifested on single plants or weeds. Therefore, one of major methods for detection of viral diseases of cereals is close and regular examination of plants in main cultivation regions. Such measures can facilitate determining the incidence of viral diseases of cereals, spread of pathogens, and constant monitoring of potential epiphytoties.

3. Infestation (points) of winter and spring wheat crops by winter wheat Russian mosaic virus (WWRMV) in different years of observation (experimental field of Research and Development Institute of Agriculture of the South-East, Saratov)

\begin{tabular}{|c|c|c|c|c|c|c|}
\hline \multirow{3}{*}{ Variety } & \multicolumn{6}{|c|}{ Time of assessment (phenophase) } \\
\hline & \multicolumn{2}{|c|}{ tillering } & \multicolumn{2}{|c|}{ onset of booting } & \multicolumn{2}{|c|}{ earing } \\
\hline & 2010 & 2011 & 2010 & 2011 & 2010 & 2011 \\
\hline \multirow{2}{*}{\multicolumn{7}{|c|}{ Winter wheat }} \\
\hline Saratovskaya 17 & & & & & & 3 \\
\hline Saratovskaya 90 & 2 & 2 & 3 & 3 & 4 & 3 \\
\hline \multirow{2}{*}{\multicolumn{7}{|c|}{ Spring wheat }} \\
\hline Saratovskaya 68 & 2 & 1 & & 2 & 3 & 2 \\
\hline Saratovskaya 73 & 1 & 1 & 1 & 2 & 2 & 3 \\
\hline
\end{tabular}

These results confirmed the findings of other researchers that WWRMV is the most common and harmful viral disease of wheat in the Lower Volga region (6). Growing leaves of the infected plants exhibited a mosaic of light-green stripes and dotted lines along the veins. Later these leaves became denser and rolled in tubes. The damaged plants showed stunt and excessive tillering leading to formation of leaf rosettes. The rosette plants usually didn't develop productive stems and dried out. On dwarf plants the mosaic was absent. Affected plants exhibited delay of earing, deformed ears, often - sterile flowers.

Thus, the year 2009 previous to the start of these observations was favorable for development of viral diseases on cereals. According to reports of the Russian Agricultural Center (Rosselkhoztsentr) of Saratov Oblast, in some of its regions (Pugachevsky, Ivanteevsky, Balakovsky, etc.) there was a severe damage of spring and winter wheat caused by viral diseases, in particular WWRMV. A large acreage didn't come into ear. As a result, there occurred a significant accumulation of insect vectors including leafhoppers. This insect population was highly viruliferous, which resulted in the great extension of viral diseases in 2010. Overwintered WWRMV-infected plants of winter wheat manifested enhanced tillering with leaf rosettes and leaf mosaic. In 2011, winter wheat was less damaged by the disease compared with 2010 (due to the decline in population of vectors), and already at tillering the symptoms of WWRMV were observed on individual plants of a winter variety Saratovskaya 17 (1-5\% plants), and about $10 \%$ damaged plants of cv Saratovskaya 90. Extension of the infection increased with the passage of phenological stages. In the phase of booting, winter variety Saratovskaya 90 in both years of observation had the damage of 10-30\%. At earing of 2010, 30\% damaged plants was recorded in the studied winter wheat cultivars (Table 3, Fig. 2).

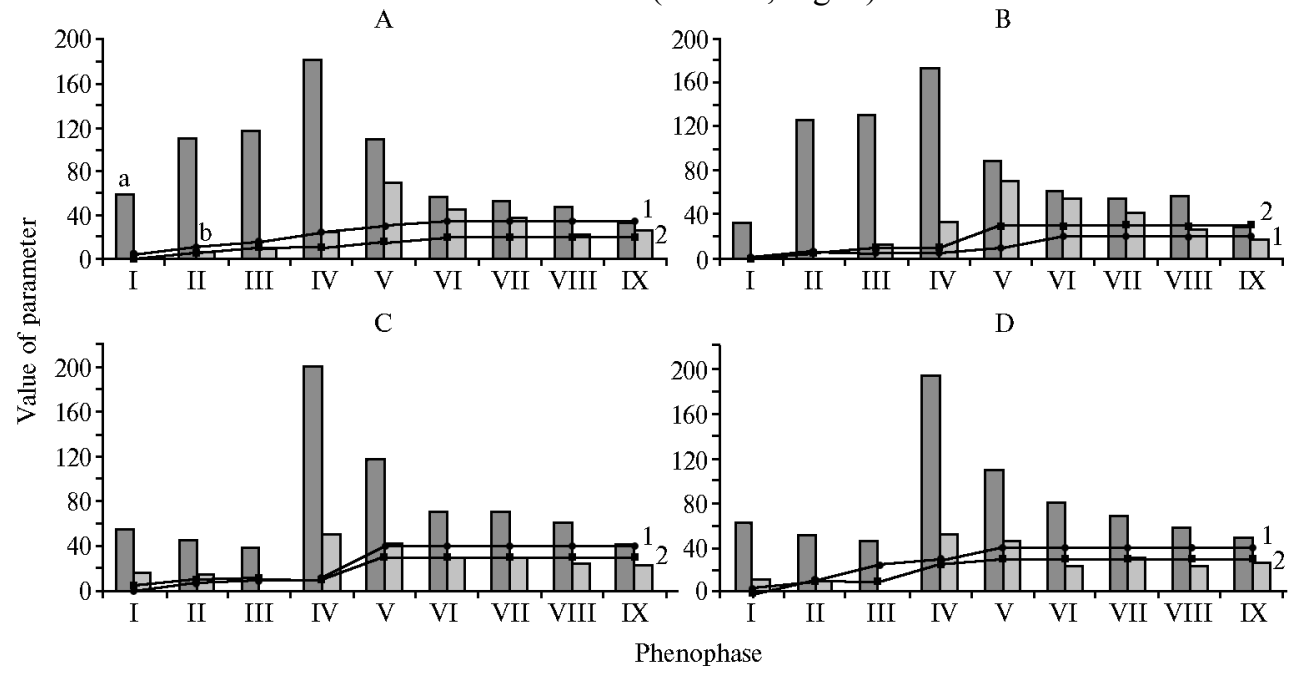


Fig. 2. Infestation level (\%) of spring wheat cultivars Saratovskaya 68 (A), Saratovskaya 73 (B), and winter wheat cultivars Saratovskaya 17 (C), Saratovskaya 90 (D) by winter wheat Russian mosaic virus (WWRMV) (chart) and population of leafhopeer Psammotettix striatus L. (number of individuals counted per sampling - 25 sweeps of a sweep-net) (bar diagram) in different years of observation: $a, 1-2010, b, 2-$ 2011; I - sprouts, II — tillering, III — onset of booting, IV — booting, V — earing, VI — flowering, VII - grain formation, VIII - milk ripeness, IX - milky-wax ripeness, X - wax ripeness, XI - complete ripeness. Number of individuals was counted per 25 sweeps of a sweep-net (mean of 4 repetitions; experimental field of Research and Development Institute of Agriculture of the South-East, Saratov)

In spring wheat, as well as in winter wheat, the early symptoms of viral pathology (leaf mosaic of pale green and yellow stripes along the veins, growth stunt, and death of leaf parts) were observed at tillering (Table 3). In 2010, spring wheat cv Saratovskaya 68 was damaged by WWRMV at 10\%, in 2011 - about twice less (up to 5\%). In 2010, the level of damage in spring wheat cultivars at earing amounted 30\%, in $2011-10 \%$. Most of the infected plants didn't come to earing or completely died (Fig. 2).

So, leafhopper Psammotettix striatus L. is the main vector for Winter Wheat Russian Mosaic Virus (WWRMV) in the Lower Volga region. Large population of the insect vectors, their viruliferous capacity along with weather conditions optimal for overwintering and further development of adults, are the main causes of viral infection of wheat that may grow up to epiphytoties.

\section{REFERENCES}

1. Panarin I.V. Metodicheskie ukazaniya po vyyavleniyu i meram bor'by s virusnymi i mikoplazmennymi boleznyami zlakov [Guidelines on Identification and Combating Viral and Mycoplasmous Diseases of Cereal Crops]. Krasnodar, 1978.

2. Mozhaeva K.A. Virusnye bolezni zlakov v Rossii i Ukraine [Viral Infections of Cereal Crops in Russia and Ukraine]. Moscow, 2003.

3. Vlasov Yu.I., Larina E.I. Sel'skokhozyaistvennaya virusologiya [Agricultural Virusology]. Moscow, 1982.

4. Markelova T.S., Kirillova T.V. Zashchita i karantin rastenii, 2010, 4: 21-23.

5. Razvyazkina G.M. Virusnye zabolevaniya zlakov [Viral Diseases of Cereals]. Novosibirsk, 1975.

6. Dubonosov T.S., Panarin I.V., Kanevcheva I.S. Virusnye bolezni zlakov [Viral Diseases of Cereals]. Moscow, 1975.

7. Fundamental'naya fitopatologiya /Pod red. Yu.T. D'yakova [Fundamental Phytopathology. Yu.T. D'yakov (ed.)]. Moscow, 2012.

8. Markelova T.S., Kirillova T.V. Agrarnyi vestnik Yugo-Vostoka, 2009, 1: 34-35.

9. Koishibaev M. Bolezni zernovykh kul'tur [Diseases of Grain Crops]. Almaty, 2002.

10. Kalmykov I.S. Agroekologicheskoe obosnovanie zashchity posevov yarovoi pshenitsy ot tsikadok (Cicadinea) v usloviyakh Nizhnego Povolzh'ya. Avtoreferat kandidatskoi dissertatsii [Agroecological Bases of Protecting Spring Wheat against Leafhoppers (Cicadinea) in Conditions of Low Volga Region, Extended Abstract of Cand. Sci. Dissertation]. Saratov, 2009.

11. Nikolenko M.P., Omel'chenko L.I. Preduprezhdenie poter' urozhaya ozimoi pshenitsy ot virusnykh boleznei i ikh perenoschikov na Yuge USSR: rekomendatsii [Recommendations for Preventing Crop Damage of Wheat Caused by Viral Diseases and Their Transmitting Vectors in the South of USSR]. Odessa, 1985.

12. Razvyazkina G.M. Rekomendatsii po obsledovaniyu zlakov na porazhennost' virusnymi boleznyami [Recommendations on Examining Cereals for Virus Infestation]. Moscow, 1965. 